\title{
Pediatric systemic lupus erythematosus and human parvovirus B19 infection
}

\author{
V Bélien-Pallet ${ }^{1}$, S Sauvion ${ }^{1}$, R Salomon ${ }^{2}$, P Quartier $^{3}$, B Bader-Meunier ${ }^{3^{*}}$ \\ From 18th Pediatric Rheumatology European Society (PReS) Congress \\ Bruges, Belgium. 14-18 September 2011
}

\begin{abstract}
Aim
To describe presentation and course of paediatric systemic lupus erythematosus (pSLE), associated with Parvovirus B19(PB19) primo-infection.
\end{abstract}

\section{Methods}

Retrospective monocentric study of patients with pSLE, defined according to ARA criteria, diagnosed before 16 years old, and associated with PB19 primo-infection, defined by the presence of PB19 IgM antibodies and PB19 DNA detected by PCR in blood and/or in tissue.

\section{Results}

3 girls aged from 8 years to 15 years 8 months have been included. PB19 infection was present at diagnosis in all patients. Maternal history of autoimmune diseases was noted in a consanguineous family. Clinical manifestations at diagnosis were fever(3), arthritis/arthralgia (3), skin rash (1), grade IV glomerulonephritis (1), interstitial pneumonia (1), cerebral vasculitis (1), pericarditis/pleurisy (1), adenopathy (2), hepatomegaly/splenomegaly (1). Aregenerative anaemia requiring packed red blood cell transfusion was present in all patients. AAN (3), anti -DNA (3), anti-SSa (1), anti-SSb (1), anti-phospholipid (1), anti-platelet (2), rheumatoid factor (2), pANCA (1), anti-actin (1) antibodies were found. PB19 PCR was positive in blood (3), bone marrow (2) and kidney (1). Corticosteroids have been initiated for the 3 patients, in association with one or more immunosuppressive therapies. A sustained remission has been observed in 2 patients after a follow-up of 4 years and 1 year 8 months off-therapy respectively. A severe course with joint damages, recurrent pericarditis and gradeIV glomerulonephritis, associated with persistent

\footnotetext{
* Correspondence: brigitte.bader-meunier@nck.aphp.fr

${ }^{3}$ Pediatric Immunology Rhumatology unit, 75015 Paris, France

Full list of author information is available at the end of the article
}

infection by PB19, has been observed in the third case (family autoimmunity history).

\section{Conclusion}

PB19 infection-associated-pSLE may evolve either to a persistent remission off-therapy or to a severe pSLE. It should be considered in patient with PSLE associated with a severe aregenerative anemia.

\section{Author details}

${ }^{1}$ Pediatric unit, Jean Verdier hospital, 93140 Bondy, France. ${ }^{2}$ Pediatric Nephrology unit, Necker hospital, 75015 Paris, France. ${ }^{3}$ Pediatric Immunology Rhumatology unit, 75015 Paris, France.

Published: 14 September 2011

\section{doi:10.1186/1546-0096-9-S1-P267}

Cite this article as: Bélien-Pallet et al.: Pediatric systemic lupus erythematosus and human parvovirus B19 infection. Pediatric Rheumatology 2011 9(Suppl 1):P267.
Submit your next manuscript to BioMed Central and take full advantage of:

- Convenient online submission

- Thorough peer review

- No space constraints or color figure charges

- Immediate publication on acceptance

- Inclusion in PubMed, CAS, Scopus and Google Scholar

- Research which is freely available for redistribution

Submit your manuscript at www.biomedcentral.com/submit
() Biomed Central 